\title{
KAJIAN PEMILIHAN MATERIAL MECHANICAL, ELECTRICAL, DAN PLUMBING RAMAH LINGKUNGAN PADA PROYEK SPORT CENTER MARANATHA DARI PRESPEKTIF PERENCANA
}

\author{
Deni Setiawan ${ }^{1}$, Michael Kristianto Marbun ${ }^{2}$ \\ ${ }^{1}$ Dosen Program Studi S-1 Teknik Sipil, Fakultas Teknik, Universitas Kristen Maranatha \\ ${ }^{2}$ Alumni Program Studi S-1 Teknik Sipil, Fakultas Teknik, Universitas Kristen Maranatha \\ Jalan Prof. Drg. Suria Sumantri No. 65, Bandung 40164 \\ e-mail: deni.setiawan@eng.maranatha.edu
}

\begin{abstract}
ABSTRAK
Pada tahap perencanaan dan pelaksanaan proyek konstruksi pemilihan material bangunan haruslah tepat namun juga harus efisien. Dampak setiap material berbeda berdasarkan pada kontaminasi dan fungsi bahan di setiap tahap siklus hidupnya dimulai dari tahap produksi sampai akhir masa layanya, oleh karena itu material dengan dampak rendah atau tidak berdampak sama sekali kepada manusia dan lingkungan dapat meminimalkan energi yang terkandung seperti meminimalkan emisi karbon dioksida, polusi udara dalam ruangan, dan daur ulang. Untuk itu strategi material ramah lingkungan saat ini sangat diperlukan untuk mencapai keberlanjutan dalam material bangunan. Tujuan penelitian ini adalah mengkaji pemilihan material material mechanical, electrical, dan plumbing yang digunakan pada proyek Sport Center Maranatha berdasarkan prespektif konsultan perencana. Hasil wawancara yang telah dilakukan kepada narasumber di dapat evaluasi bahwa dalam sistem MEP proyek Sport Center Maranatha memang tidak di rancang mengikuti kaidah ramah lingkungan sehingga dalam pemilihan setiap material yang digunakan pun lebih ditekankan kepada bagaimana memperoleh setiap material berdasarkan ketersediaan pasar atau kemudahan dalam mendapatkan setiap produk material
\end{abstract}

Kata Kunci: Keberlanjutan, material ramah lingkungan, mechanical, electrical, plumbing

\section{ABSTRACT}

In the planning and implementation stages of a construction project the selection of building materials must be precise but also efficient. The impact of each material is different based on contamination and the function of the material at each stage of its life cycle starting from the production stage until the end of its service life, therefore materials with low impact or have no impact on humans and the environment can minimize the energy contained such as minimizing carbon dioxide emissions, indoor air pollution, and recycling. For this reason, a sustainability material strategy is now needed to achieve sustainability in building materials. The purpose of this study is to examine the selection of mechanical, electrical and plumbing materials used in the Maranatha Sport Center project based on the perspective of the planning consultant. The results of interviews conducted with informants can be evaluated that in the MEP system the Maranatha Sport Center project was not designed to follow green material rules so that in the selection of each material used it was more emphasized on how to obtain each material based on market availability or ease in getting each product material

Keywords: Sustainability, green materials, mechanical, electrical, plumbing

\section{Pendahuluan}

Pada tahap perencanaan dan pelaksanaan proyek konstruksi pemilihan bahan atau material bangunan haruslah tepat namun juga harus efisien. Konsep eco-efficiency diperkenalkan pada 1991 oleh World Business Council for Sustainable Development - 
WBCSD dan termasuk juga "pengembangan produk dan layanan yang memiliki harga kompetitif yang memenuhi kebutuhan kualitas hidup manusia, sementara secara progresif mengurangi dampak kepada lingkungan dan konsumsi bahan baku sepanjang siklus hidupnya sesuai dengan kapasitas yang ada di planet bumi." Konsep ini berarti memproduksi lebih banyak produk dengan sumber daya yang lebih sedikit dan limbah yang lebih sedikit, maka dari itu konsep ini memberikan dampak yang lebih sedikit kepada lingkungan.

Penggunaan material ramah lingkungan dalam konsensus untuk seluruh dunia pada masalah ini dalam aksi nyata belum tercapai dikarenakan setiap negara memiliki tingkat perkembangan yang berbeda - beda. (Pacheco Torgal dan Jalali, 2011) Pada negara berkembang sudah seharusnya berkontribusi dengan menerapkan standar atau regulasi yang tinggi terhadap dampak lingkungan termasuk di Indonesia dalam dunia konstruksi. Tujuan penelitian ini adalah mengkaji pemilihan material material mechanical, electrical, dan plumbing yang digunakan pada proyek Sport Center Maranatha berdasarkan prespektif konsultan perencana. Adapun lokasi proyek Sport Center Maranatha terletak di dalam kawasan Kampus Universitas Kristen Maranatha Bandung yang beralamat di Jl. Surya Sumantri No.65, Sukawarna, Kec. Sukajadi, Kota Bandung, Jawa Barat.

\section{Tinjauan Pustaka}

\subsection{Keberlanjutan Dan Konstruksi}

Dalam beberapa dekade terakhir muncul suatu bentuk pemahaman baru dikalangan praktisi industri teknik sipil, pemahaman tersebut merupakan pengembangan dari konsep berkelanjutan yaitu konstruksi berkelanjutan (Sustainability Constuction). Konstruksi berkelanjutan adalah proses holistik yang bertujuan untuk memulihkan dan menjaga keharmonisan antara lingkungan alam dan bangunan, dan menciptakan solusi yang menegaskan martabat manusia dan mendorong kesetaraan ekonomi. Harus diakui bahwa umat manusia terkunci dalam hubungan yang sangat dinamis dengan dunia alami dan bahwa keduanya sangat saling bergantung. Dalam mengatasi masalah kompleks konstruksi dan lingkungan, upaya menuju konstruksi berkelanjutan pada dasarnya merupakan upaya untuk menerapkan praktik yang mengembalikan keseimbangan antara lingkungan alam dan bangunan.

Disetiap negara, pemahaman tentang konstruksi berkelanjutan berbeda bergantung kepada tingkat kekuatan ekonomi negara yang bersangkutan. Di negara berkembang seperti Indonesia, keberlanjutan yang dimaksud lingkungan hidup dalam 
Undang Undang No. 23 Tahun 1997 adalah: "kesatuan ruang dengan semua benda, daya, keadaan, dan makhluk hidup, termasuk manusia dan perilakunya, yang mempengaruhi kelangsungan perikehidupan dan kesejahteraan manusia serta makhluk hidup lain". Definisi lain yang cukup baik dalam menerangkan mengenai konstruksi berkelanjutan adalah sebagai suatu kegiatan menciptakan dan mengoperasikan lingkungan terbangun (built environment) yang sehat didasarkan atas prinsip efisiensi sumber daya dan desain ekologi, serta mengikuti tujuh (7) prinsip konstruksi berkelanjutan yang harus dipenuhi dalam setiap fase kegiatan desain dan konstruksi yang berlanjut selama keseluruhan siklus hidup bangunan tersebut (Kibert, 2016). Ketujuh prinsip konstruksi berkelanjutan tersebut antara lain adalah:

1. Mengurangi konsumsi sumber daya (reduce)

2. Penggunaan kembali sumber daya (reuse)

3. Menggunakan sumber daya yang terdaur ulang (recycle)

4. Melindungi lingkungan (protect nature)

5. Menghilangkan racun (eliminate toxics)

6. Menerapkan konsep biaya siklus hidup (life cycle costing)

7. Fokus kepada kualitas (focus on quality)

Ketujuh prinsip konstruksi berkelanjutan dari Kibert tersebut harus dilaksanakan secara integratif pada setiap tahapan dari suatu proyek.

\subsection{Keberlanjutan Dan Material Konstruksi}

Pada dasarnya suatu material konstruksi merupakan komponen yang sangat penting dalam menentukan biaya suatu proyek karena meliputi seluruh bahan yang dibutuhkan untuk menyelesaikan bagian pekerjaan dalam satu kesatuan pekerjaan atau proses konstruksi. Bahkan menurut hasil penelitian yang dilakukan oleh Glavinich (2008) menunjukkan bahwa material konstruksi menyumbangkan sekitar $70 \%$ dari biaya konstruksi.

Selain itu, pemilihan suatu material baik dapat mempengaruhi kualitas dari proyek konstruksi tersebut. Jenis-jenis material konstruksi dibagi menjadi empat kelompok, yaitu:

1. Raw Material (bahan baku)

2. Material Jadi

3. Material campuran

4. Material prefab 


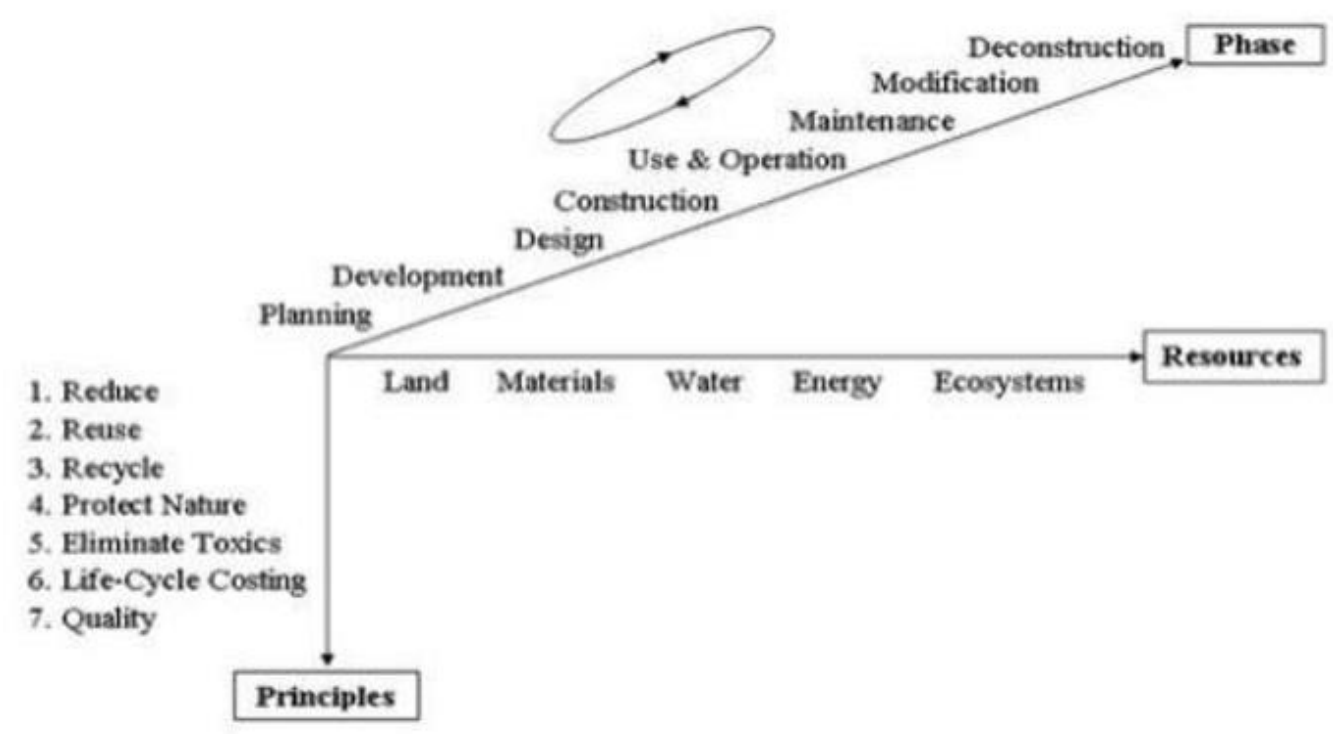

Gambar 1. Konsep Konstruksi Berkelanjutan. Sumber: Kibert, 2016

Sedangkan dari segi arus penggunaan, material konstruksi akan dimulai sejak pengiriman ke lokasi proyek, proses konstruksi, sampai pada posisinya yang terakhir akan berakhir pada salah satu dari keempat posisi dibawah ini (Gavilian dan Bernold, 1994), yaitu:

1. Strukstur fisik bangunan

2. Kelebihan material

3. Digunakan kembali pada proyek yang sama

4. Sisa material (waste)

Adapun identifikasi terkait siklus hidup suatu material yang diasosiasikan dengan lingkungan, khususnya emisi karbon, saat ini terdapat 5 tipe cakupan batasan yang cukup dikenal yaitu (Richardson, 2013):

1. Cradle-to-Gate

2. Cradle-to-Site

3. Cradle-to-End Of Construction

4. Cradle-to-Grave

5. Cradle-to-Cradle

Green Construction Material pada dasarnya memiliki arti yang lebih luas dari sekedar material ramah lingkungan. Pengertian material ramah lingkungan pada umumnya menyangkut dari sisi produk material itu sendiri, yaitu material yang pada saat 
digunakan dan dibuang, tidak memiliki potensi merusak lingkungan dan mengganggu kesehatan. Sedangkan Green Construction Material, tidak hanya menilai dari sekedar keluaran produk yang ramah lingkungan tetapi juga meninjau sumber materialnya apakah berkelanjutan?; Apakah proses produksinya di pabrik juga ramah lingkungan?; Apakah proses distribusinya jauh sehingga membuang banyak karbon?; Apakah proses pemasangannya tidak membuang banyak sisa sampah?; Apakah dapat mendukung penghematan energi?;, sehingga dalam perencanaan suatu bangunan hijau (Green Building), Green Construction Material tersebut dapat secara dinamis memberikan dampak terhadap penghematan listrik, penghematan air, meningkatkan kesehatan dan kenyamanan, dan efisiensi manajemen perawatan bangunannya.

\section{Metodologi Penelitian}

Metode penelitian pada dasarnya merupakan cara ilmiah untuk mendapatkan data yang diperlukan dalam penelitian sesuai dengan tujuan dan kegunaan dari penelitian ini. Cara ilmiah berarti kegiatan penelitian didasarkan pada ciri-ciri keilmuan, yaitu: rasional, empiris, dan sistematis. Rasional berarti kegiatan penelitian dilakukan dengan cara-cara yang masuk akal, sehingga terjangkau oleh penalaran manusia. Empiris berarti cara-cara yang dilakukan itu dapat diamati oleh indra manusia, sehingga orang lain dapat mengamati dan mengetahui cara-cara yang digunakan. Sistematis artinya proses yang digunakan dalam penelitian ini menggunakan langkah-langkah tertentu yang bersifat logis (Sugiyono, 2012).

Metode deskriptif dikelola untuk memperoleh suatu gambaran mengenai peristiwa yang ada saat ini di lokasi yang diteliti atau yang dijadikan objek penelitian untuk memperoleh suatu permasalahan yang akan dilakukan analisis atau identifikasi. Biasanya penelitian dengan metode deskriptif dilakukan apa bila sumber yang akan diteliti menarik dan dapat digambarkan secara faktual dan cermat.

Data yang diambil berupa data primer dan data sekunder, baik secara langsung atau tidak langsung. Adapun pengambilan data primer berupa observasi langsung ke lokasi proyek, survei melalui wawancara kepada pihak konsultan, serta investigasi dengan mengakses data spesifikasi setiap material yang digunakan.

\section{a. Pengolahan Data}

Pengolahan data dalam penelitian ini dibagi menjadi beberapa tahapan; 
1. Kajian data sekunder berupa pengklasifikasian material mechanical, electrical, dan plumbing pada proyek Sport Center Maranatha.

2. Penyusunan instrumen penelitian berupa identifikasi variabel dan indikator material konstruksi hijau untuk kriteria sumber dan siklus material tahapan material-life-span.

3. Observasi, dilakukan hanya untuk mendapatkan kesesuaian data antara data yang diperoleh dari data spesifikasi teknis dengan material yang sesungguhnya dipergunakan di lapangan.

4. Melakukan wawancara kepada konsultan selaku konsumen material konstruksi untuk tahapan material-life-span.

5. Investigasi setiap material yang dipergunakan melalui analisa potensi kriteria hijau pada setiap material konstruksi dengan melakukan investigasi dengan cara mengakses data spesifikasi produk untuk setiap material melalui website resmi lembaga merek produk material.

\section{Hasil Analisis Data}

\subsection{Analisis Deskriptif melalui Wawancara}

Dalam penelitian ini, wawancara mendalam (in-depth interview) dipilih sebagai metode pengumpulan data. Untuk itu, narasumber yang dipilih guna mengkaji dan menganalisis material konstruksi ramah lingkungan di proyek Sport Center Maranatha adalah Pihak Konsultan perencana sistem $M E P$, sebagai Konsultan yang merancang dan merencanakan seluruh sistem $M E P$, sehingga dapat berfungsi dan memenuhi syarat sebagaimana mestinya.

\subsection{Struktur Wawancara}

Metode wawancara yang digunakan adalah semi-terstruktur dimana pewawancara memiliki kerangka pertanyaan di awal namun dapat memberikan tanggapan berupa pertanyaan lanjutan sesuai dengan jawaban narasumber. Beberapa tahapan dalam wawancara yang akan diselenggarakan adalah sebagai berikut:

1. Pertanyaan pembuka (opening questions). Dalam tahap ini pewawancara berupaya memfokuskan perhatian narasumber terhadap pokok bahasan terkait material/produk kontruksi terkait. Hal ini dilakukan dengan mengklarifikasi peran atau perhatian serta wawasan yang relevan dengan pandangan narasumber terhadap produk material ramah lingkungan. Narasumber juga diminta untuk menceritakan langkah awal penentuan atau pemilihan material/produk yang digunakan. 
2. Eksplorasi isu utama (main issues explorations). Dalam tahap ini pewawancara memaparkan berbagai kriteria hijau dengan pendekatan by process (siklus hidup material pada tahapan material-life-span) yang teridentifikasi pada latar belakang penelitian dan meminta narasumber untuk memberikan pendapat terkait material.

\subsection{Hasil Wawancara}

Berikut ini adalah hasil wawancara yang dilakukan kepada narasumber disajikan dalam tabel 1 sebagai berikut.

Tabel 1. Hasil Wawancara kepada Narasumber

\begin{tabular}{|c|c|c|c|c|c|}
\hline No & $\begin{array}{c}\text { Kelompok } \\
\text { Pertanyaan } \\
\end{array}$ & No & $\begin{array}{c}\text { Pertanyaan } \\
\text { Utama }\end{array}$ & $\begin{array}{c}\text { Tujuan } \\
\text { Pertanyaan }\end{array}$ & $\begin{array}{c}\text { Pertanyaan } \\
\text { Follow-Up }\end{array}$ \\
\hline \multirow[t]{4}{*}{1} & $\begin{array}{c}\text { Opening } \\
\text { Questions / } \\
\text { Warming } \\
\text { Up }\end{array}$ & 1.1 & $\begin{array}{l}\text { Apa yang anda } \\
\text { ketahui terkait } \\
\text { konsep material } \\
\text { konstruksi ramah } \\
\text { lingkungan? }\end{array}$ & $\begin{array}{l}\text { Untuk mengetahui } \\
\text { pandangan } \\
\text { narasumber terkait } \\
\text { material } \\
\text { konstruksi hijau }\end{array}$ & $\begin{array}{l}\text { - Mengapa Anda } \\
\text { berpendapat } \\
\text { demikian? } \\
\text { - Apakah yang } \\
\text { menjadi dasar dari } \\
\text { pendapat Anda? }\end{array}$ \\
\hline & & & \multicolumn{3}{|c|}{$\begin{array}{l}\text { Jawaban: Menurut pandangan saya material ramah lingkungan } \\
\text { adalah material yang secara bahan merupakan bahan ramah } \\
\text { lingkungan. Namun untuk material } M E P \text { secara bahan tidak } \\
\text { akan ada material yang ramah lingkungan. Terkecuali misalkan } \\
\text { ada material stop kontak, terbuat misalnya dari bahan kayu, } \\
\text { tetapi material seperti itu akan sulit sekali di cari. }\end{array}$} \\
\hline & & 1.2 & $\begin{array}{l}\text { Apakah dalam } \\
\text { perencanaan } \\
\text { sistem } M E P \\
\text { dirancang } \\
\text { mengikuti kaidah } \\
\text { "ramah } \\
\text { lingkungan"? }\end{array}$ & $\begin{array}{l}\text { Untuk mengetahui } \\
\text { sejauh mana } \\
\text { proyek } \\
\text { menerapkan } \\
\text { kaidah "ramah } \\
\text { lingkungan" }\end{array}$ & $\begin{array}{l}\text { - Mengapa Anda } \\
\text { berpendapat } \\
\text { demikian? } \\
\text { - Apakah yang } \\
\text { menjadi dasar dari } \\
\text { pendapat Anda? }\end{array}$ \\
\hline & & & \multicolumn{3}{|c|}{$\begin{array}{l}\text { Jawaban: Menurut saya dikarenakan untuk memilih material } \\
M E P \text { sangat sulit untuk mencari yang mengikuti konsep ramah } \\
\text { lingkungan, yang pertama saya tidak punya pilihan. Terkeciali } \\
\text { untuk AC, AC yang digunakan dipilih karena menggunakan } \\
\text { refrigeran R32 yang memiliki konsep hemat energi. selain itu } \\
\text { saya lebih memfokuskan setiap material sebagaimana fungsi } \\
\text { utamanya. }\end{array}$} \\
\hline
\end{tabular}


Tabel 1 (Lanjutan)

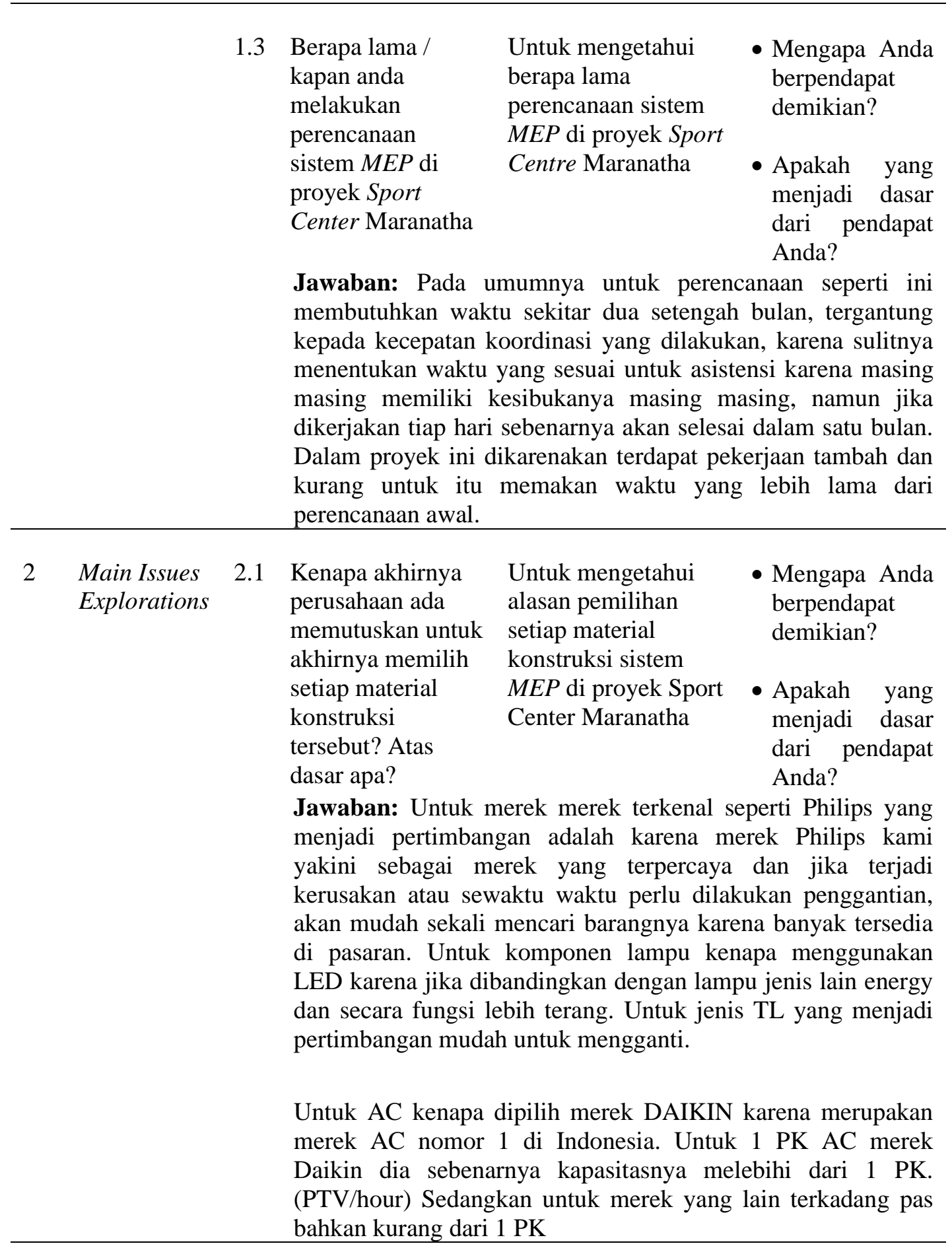




\begin{tabular}{|c|c|c|c|}
\hline & & & $\begin{array}{l}\text { Untuk exhaust fan bermerek KDK. Saya berpengalaman } \\
\text { menggunakan exhaust fan dengan merek lain. Mungkin untuk } \\
\text { pertimbangan harga lebih murah tapi secara ketahanan. Merek } \\
\text { KDK yang merupakan keluaran Jepang ini lebih tahan lama. } \\
\text { Dan sudah saya rasakan sendiri exhaust Fan KDK tidak berisik } \\
\text { dibandingkan dengan merek yang lain dan sampai } 5 \text { tahun pun } \\
\text { masih awet. } \\
\text { Untuk konponen panel kenapa memilih Schenider, banyak, } \\
\text { murah, mudah dan merek ini termasuk merek yang menguasi } \\
\text { banyak pasar. }\end{array}$ \\
\hline 3 & $\begin{array}{l}\text { Product } \\
\text { Evaluation }\end{array}$ & 3.1 & $\begin{array}{lll}\begin{array}{l}\text { Kendala apa yang } \\
\text { di alami pada saat }\end{array} & \begin{array}{l}\text { Untuk mengetahui } \\
\text { kendala yang di } \\
\text { proses }\end{array} & \begin{array}{l}\text { Apa yang } \\
\text { dilakukan untuk } \\
\text { perencanaan }\end{array} \\
\text { proses perencanaan } & \text { mengatasi } \\
\text { sistem } M E P \text { di } & \text { sistem } M E P \text { di } & \\
\text { proyek Sport } & \text { proyek Sport Center } & \\
\text { Center Maranatha } & \text { Maranatha } & \\
\text { Jawaban: Untuk perencanaan yang menjadi kendala adalah } \\
\text { menyeimbangkan biaya dengan kebutuhan. Masing masing hal } \\
\text { tersebut harus reasonable. Kita diberikan tugas untuk } \\
\text { mengikuti kemauan owner atau pemberi tugas. Sekalipun } \\
\text { terjadi perubahan di tengah tengah, dan juga harus juga mampu } \\
\text { berkoordinasi dengan pihak yang lain seperti desain dan lain } \\
\text { lain. }\end{array}$ \\
\hline
\end{tabular}

Berdasarkan hasil investigasi data produk yang sudah diidentifikasi melalui pemetaan indikator/kriteria hijau dan berdasarkan hasil survei expert judgment yang telah dilakukan kepada kontraktor melalui kueisoner pemetaan indikator/kriteria hijau (khosnava) untuk tahapan material-life-span, menghasilkan kriteria hijau utama yang merupakan kriteria hijau yang memenuhi di kedua cara penilaian di tunjukan dalam Tabel 2 sebagai berikut:

Tabel 2. Variabel Kriteria Hijau Utama

\begin{tabular}{|c|c|c|}
\hline No. & Material & Variabel Kriteria Hijau Utama \\
\hline \multicolumn{3}{|c|}{ I. Material Mechanical } \\
\hline 1 & Unit AC & - Energy Efficiency During Operation \\
\hline 2 & Exhaust Fan & - Durable \\
\hline & & - Energy Efficiency During Operation \\
\hline 3 & Ventilating Fan & - Durable \\
\hline \multicolumn{3}{|c|}{ II. Material Electrical } \\
\hline 4 & Kabel (Building Wire) & - Energy Efficiency During Operation \\
\hline 5 & Conduit + Acc. & $\begin{array}{ll}\text { - } & \text { Durable } \\
\text { - Energy Efficiency During Operation }\end{array}$ \\
\hline
\end{tabular}


Tabel 2 (Lanjutan)

\begin{tabular}{|c|c|c|}
\hline 6 & Saklar / Stop Kontak & - Low VOC Assembly \\
\hline 7 & Armature Lampu Balk $L E D$ & $\begin{array}{l}\text { - } \quad \text { Energy Efficiency During Operation } \\
\text { - Durable } \\
\text { - Energy Efficiency During Operation }\end{array}$ \\
\hline 8 & Armature Lampu Baten $L E D$ & - Energy Efficiency During Operation \\
\hline 9 & Armature Lampu Downlight LED & - Energy Efficiency During Operation \\
\hline 10 & $\begin{array}{c}\text { Armature Lampu Downlight LED } \\
\text { Ruangan }\end{array}$ & - Energy Efficiency During Operation \\
\hline 11 & Armature Lampu Floodlight LED & $\begin{array}{l}\text { - } \quad \text { Durable } \\
\text { - Energy Efficiency During Operation } \\
\text { - Affordability During Operation }\end{array}$ \\
\hline 12 & Komponen Panel $M C B$ & - Low VOC Assembly \\
\hline 13 & Komponen Panel Kontaktor & $\begin{array}{ll}- & \text { Low VOC Assembly } \\
\text { - } & \text { Healthfully Maintained }\end{array}$ \\
\hline
\end{tabular}

\section{Material Plumbing}

14

$\begin{array}{cl}\text { Sewage Pipes } & \text { - Durable } \\ & \bullet \text { Energy Efficiency During Operation } \\ & \bullet \text { Affordability During Operation } \\ \text { Packaged Sewage Treatment Plan } & \bullet \text { Energy Efficiency During Operation } \\ & \bullet \text { Affordability During Operation }\end{array}$

\section{Simpulan}

Berdasarkan hasil wawancara yang telah dilakukan kepada narasumber di dapat evaluasi bahwa dalam sistem MEP proyek Sport Center Maranatha memang tidak di rancang mengikuti kaidah ramah lingkungan sehingga dalam pemilihan setiap material yang digunakan pun lebih ditekankan kepada bagaimana memperoleh setiap material berdasarkan ketersediaan pasar atau kemudahan dalam mendapatkan setiap produk.

\section{DAFTAR PUSTAKA}

1. Alfiana, M. D., 2017, Analisis Aspek Sumber Dan Siklus Material Green Construction Pada Proyek Apartemen Grand Kamala Lagoon. Institut Pertanian Bogor

2. Bhatia, A., n.d., The MEP Design of Building Services Diedit oleh CED Enginneering. M06-034 ed. New York: Continuing Education and Development; Inc

3. Department of, dan Education and Science Tullamore, C. O., 2004, Mechanical \& Electrical Building Services Engineering Guidelines for Primary School Buildings, Mechanical \& Electrical Building Services Engineering Guidelines for Primary School Buildings TGD 0021 (February) 
4. Flores, M., Maklin, D., Ingram, B., Golob, M., Tucci, C., dan Hoffmeier, A., n.d., Towards a Sustainable Innovation Process: Integrating Lean and Sustainability Principles, 1-8

5. GBCI (Green Building Council Indonesia), 2013, Greenship Untuk Bangunan Baru Versi 1.2. 1.2, issued 2013

6. GBCI (Green Building Council Indonesia), 2019, Tentang GBC Indonesia, http://www.gbcindonesia.org/

7. Grondzik, W. T., Kwok, A. G., Stein, B., dan Reynolds, J. S., 2010, Mechanical and Electrical Equipment For Buildings. Eleventh E. Canada: John Wiley \& Sons, Inc.

8. Khoshnava SM, Rostami R, Valipour A, Ismail M, Rahmat AR, Rank of green building material criteria based on the three pillars of sustainability using the hybrid multi criteria decision making method, Journal of Cleaner Production (2016), doi: 10.1016/j.jclepro.2016.10.066

9. Kubba, S., 2017, Introduction, In Handbook of Green Building Design and Construction, diedit oleh Peter Jardim, Second Edi, xv-xlii. Joe Hayton, doi:10.1016/B978-0-12-810433-0.02001-3

10. Pacheco Torgal, F., dan Jalali, S., 2011, Eco-efficient Construction and Building Materials, British Library Cataloguing. London: Springer London, doi:10.1007/978-0-85729-892-8

11.Palomera-arias, R., Liu, R., dan University Of Texas, 2015, Mechanical, Electrical and Plumbing Systems in Construction Management: A Literature Review of Existing MEP Textbooks. San Antonio

12. Rani, D., 2018, Analisis Sistem Plumbing Ramah Lingkungan Di Proyek Gedung Pusat Kegiatan Badan Amil Zakat Nasional (BAZNAS). Universitas Kristen Maranatha

13. Viqolbi, M. A., 2017, Kajian Penilaian Material Konstruksi Hijau Di Indonesia. Institut Teknologi Bandung

14. Wujek, J. B., Dagostino, F. R., dan Pearson Education, I., 2010, Mechanical and Electrical Systems in Architecture, Engineering, and Construction. Fifth. New Jersey: Library of Congress Cataloging 